\title{
Analysing training needs of TVET teachers in South Africa: An empirical study
}

\author{
Bernd Zinn*, Kevin Raisch, Jennifer Reimann \\ University of Stuttgart Institute of Educational Science Department of Vocational Education \\ focused on Teaching Technology (BPT) Azenbergstr.12, 70174, Stuttgart, Germany
}

Received: 02.01.2019; Accepted: 17.04.2019; Published: 29.08.2019

\begin{abstract}
Context: This paper reports on a study of the progress of vocational education and training (VET) and the need for further profession-oriented training of lecturers in public, technical vocational colleges in South Africa, under the consideration of societal and political conditions.
\end{abstract}

Approach: The study is based on a mixed methods approach in which an analysis of educational policy documents and a qualitative and a quantitative study with VET teachers and representatives of education authorities in South Africa are conducted.

Findings: The classification of the results is conducted in line with the conditions defined by Phillips and Ochs regarding policy transfers. The following can thus be observed through the bilateral relationship between Germany and South Africa: (1) The Guiding Philosophy of the educational system is characterised by societal and political power structures. This is evident in an analysis of approved reforms within the last two decades. (2) The desired effects of "Ambitions Goals" have thus far not taken hold. Nonetheless, there is a willingness to enact reforms to continue developing vocational education, including the training and further education of lecturers that must be noted. Minimum requirements regarding lecturers' basic qualifications have been formulated, which one in five vocational lecturers in South Africa currently cannot fulfil. (3) The Strategies formulated to implement training methods face the main problem of difficulty in implementation in colleges. (4) The Enab-

*Corressponding author: zinn@ife.uni-stuttgart.de

ISSN: $2197-8646$

http://www.ijrvet.net

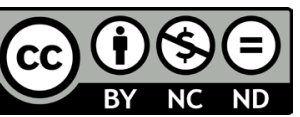


ling Structures, i.e. the education-management-system as well as the financial and personnel support of the educational system, are widely perceived by lecturers as unsupportive, ineffective and discriminatory. This is observed, for example, when looking at the equipment used, teachers' salaries, classroom sizes as well as the mentorship programme and further training opportunities. (5) Processes: a discrepancy exists on the level of the lecturers and the central need for further training regarding modern technologies, especially those used by foreign firms in their production in South Africa. (6) The results of the conducted study document a high variation of qualifications among TVET lecturers when it examines their teaching Techniques.

Conclusions: Overall, the empirical results of the study reveal a complex structure with respect to the requirements for further training of TVET lecturers, describe central needs for further training of lecturers and deliver connectable knowledge for both the practical educational advancement of lecturer training and further education training, as well as for research in the context of the internationalisation of vocational training in South Africa.

Keywords: Internationalisation, Vocational Education and Training, Vocational Teachers, Further Education, Public TVET College, South Africa, VET

\section{Introduction}

The cooperation in vocational training between the Federal Republic of Germany and other countries, especially with developing countries, as well as the related international research on vocational training have a storied tradition (Gross, 1981; Deißinger, 2001; Wolf, 2011; Barabasch \& Wolf, 2011). In the late 19th century, both the German elementary education model and the vocational training model were discussed in the Anglo-American sphere. Organised international cooperation in the form of transfers of educational structures or vocational curricula between Germany and other countries has been in effect since approximately the middle of the previous century (Ochs \& Phillips, 2002; Gonon, 2009; Barabasch \& Wolf, 2011). Currently, there are intentions to grow international educational cooperation in the discourse of united European educational reforms with several European countries (including Greece, Spain and Portugal) (Euler, 2013) as well as with non-European countries (including China, South Africa and the Russian Federation) (BMBF, 2017a). The goals of bilateral cooperation in the areas of vocational training in Germany are varied and focus on, amongst other aspects, a reorganisation of country-specific educational and training systems, interconnected with the hope that they will produce increases in the standard of education and a lowering in youth unemployment, increased competitiveness of companies or an improvement in the employability of young people. There is also strong interest in orienting this reorganisation on the dual training model (BMBF, 2017a). The importance of interna- 
tional cooperation for the expansion of vocational training cooperation has also increased significantly, due to increasing economic globalisation and further current global societal challenges, such as intercontinental refugee flows from Africa to Europe along with the apparent high regard for the German educational system (Baumgarten et al., 2017). As such, research on international vocational training is increasingly coming into focus in vocational education research (Baumgarten et al., 2017).

Since the passing of the 'strategy paper of the German government: Vocational training cooperation from a single source' (BMBF, 2017b) in 2013 and the establishment of the Federal Centre for International Vocational Training Cooperation (GOVET) within the Federal Institute for Vocational Training (BIBB), the political, societal and economical relevance of the expansion of research on an internationalisation of vocational training has become apparent.

The strategy of the German government is to strengthen foreign national systems and their dual educational training programs. This is characterised by the following five core elements: the promotion of cooperation between social partners, the inclusion of economic and state actors, learning within work processes, the acceptance of national standards, support for the training and advanced/expanded instruction of qualified vocational training teachers and the expansion of institutionalised vocational training research and vocational training counselling (BMBF, 2017b). The core elements are not limited to certain fields of educational training.

This bilateral vocational training cooperation is further outlined in five specified fields of action. There is support for vocational training reform in the form of a system consultation (1) in regard to the legal framework and the framework curricula, and (2) in regard to the establishment of vocational training colleges. (3) There is also support and encouragement for social-partnership dialogues, (4) pilot projects to train the trainers and (5) pilot projects in dual education programmes which are intended to take place in cooperation between the German Chambers of Commerce Abroad [Außenhandelskammer (AHK)], small and medium-sized businesses [Klein- und Mittelständische Unternehmen (KMU)] and vocational training institutions.

The present funding guidelines have the intention to further strengthening and developing the institutionalised vocational training research field, which is the fifth core element of the bilateral vocational training cooperation. German academic expertise in the research field of vocational training and the academic training of VET lecturers should be made available to all foreign partners in order to assist reforms of their national systems. Overall, the establishment of an interdisciplinary- and transdisciplinary research network for international vocational training collaborations should be promoted (BMBF, 2017b). Country- and state-specific challenges and characteristics associated with vocational training cooperation 
as a result of the aforementioned core elements thus become all the more obvious. In this context, Euler (2013, p. 4) writes:

If a foreign educational system is to be transferred into one's own country, existing circumstances must be considered, and the execution of dual vocational training programmes must be adjusted to local educational policies as well as social and economic goals. Thus, it is a question of a clever transfer of adapted elements and not a carbon-copy of a foreign approach.

According to the research findings and context factors of a policy transfer as defined by Phillips and Ochs, a transfer of educational systems and curricula is highly conditional on (1) the Guiding Philosophy or Ideology (i.e. the guiding philosophy of the educational system), (2) the 'Ambitions' Goals (i.e. the educational goals and requirements), (3) the Strategies (i.e. the formal and material rules and strategies for the execution of educational measures), (4) the Enabling Structures (i.e. the structures of educational authorities and the financial and personnel supply of the educational system), (5) the Processes (meaning the teaching process) and (6) the Techniques (meaning the competences of the individual teachers) (Phillips \& Ochs, 2003, pp. 329-330; see also Barabasch \& Wolf, 2011, pp. 285-289). The transfer of one state's/country's educational systems and curricula, partial or full training and advanced instruction systems into another state/country appears highly complex and is significantly affected by the technological and economic as well as historic, cultural, political and social structures of both countries/states (Phillips \& Ochs, 2003).

The research and development project, TRAINME ${ }^{1}$, in the frame of which this article is authored, focusses on the professionalisation of South African vocational lecturers (TVET 2 lecturers). The project aims to conceptualise and implement target group-specific further training modules for lecturers in the metal and electrical engineering fields as well as to promote the reputation of public vocational training colleges (public TVET colleges ${ }^{3}$ ) (European Commission, 2014, p. 45), consequently strengthening the local economy (Lumby, 2000, p. 101). The qualification of lecturers in the vocational education and training (VET) sector is a central, constituting feature of vocational training (Euler, 2013).

A fundamental step in the expansion of German-South African cooperation is the joint declaration of intent by the Department of Higher Education and Training (DHET) and the Federal Ministry of Education and Research (BMBF) and the related bilateral operational programme. This bilateral operational programme provides for the support of the continued development of the South African Vocational Training Institute (SAIVCET ${ }^{4}$ ), the trial of dual

1 The project 'Modular training and further education of South African TVET lecturers in mechanical and electrical engineering' (TRAINME) is financed by the Federal Ministry for Education and Research in line with the internationalisation of vocational training under the Financial ID 01BE17014B (Operational Timeframe: 01.01.2018 - 31.12.2020).

2 TVET means Technical and Vocational Education and Training.

3 In South Africa, there is a noticeable difference between public vocational schools (public TVET college) and private vocational schools (private TVET college). The prospects of employment after graduation differ to a vastly disproportionate degree.

4 SAIVCET (South African Institute for Vocational and Continuing Education and Training). 
training courses in South Africa, the development of vocational training standards and the assembly of curricula which align themselves more closely to the needs of the South African economy. The programme also supports the reform requirements of the training and continued education of vocational teachers (Baumgarten et al., 2017, pp. 26-27).

In addition to South Africa, other African nations such as Egypt, Ghana, Tanzania and Ethiopia have recognised the importance of highly qualified teachers and trainees at vocational colleges and, in this spirit, have declared their intention to institute appropriate reforms. These African nations are either working towards a modernisation of their educational plans and frameworks or have realised this modernisation already (Allais, 2011a; DHET, 2013a; Field, Musset \& Álvarez-Galván, 2014; Hailemichael, 2016). The government of South Africa is striving to include international standards in their curriculum planning to raise the standard of professionalisation to an internationally comparable level (Allais, 2011a; Akoojee, 2016).

In the frame of the cooperation between Germany and South Africa and under the declared goals of the TRAINME project, this article aims to systematically examine the current state of things and the reform aspirations towards the educational training of lecturers as well as the related needs for further training in South Africa. In section 2, the state of current research on the training of lecturers in South Africa is described. This section also gives specific notes for the hedging of a sustainable transfer of relevant projects in the context of an intended policy transfer, so that in section 3, the conducted research presented in the appendix can be explained. In section 4 , the results of the investigation are presented, and then in section 5, the findings are discussed in the context of links between international VET research and South Africa.

\section{State of Research}

The international state of the research leaves no doubt about the significance of lecturers' profession-related competencies in the development of their students (Shulman, 1987; Zlatkin-Troitschanskaia et. al., 2009; Terhart, Bennewitz, \& Rothland, 2014). Established models regarding professional occupational competencies usually account for four aspects of competence: vocational knowledge, beliefs/values, motivational orientations and self-regulating capabilities (Krauss et al., 2004). Vocational knowledge is further divided into four central subcategories, specifically content knowledge, pedagogical content knowledge and pedagogical-psychological knowledge as well as counselling knowledge (Baumert \& Kunter, 2011, pp. 32-33). The continued interdisciplinary training of teachers is also seen as promoting the practical teaching methods employed by lecturers for the academic success of the student (Lipowsky, 2011; Lipowsky, Rzejak \& Dorst, 2011). 
Specifically regarding competencies of and advanced training courses for South African TVET lecturers with respect to profession-related content- and subject content knowledge focussing on electrical and mechanical engineering, no empirical findings from the data under consideration in this paper demonstrate these research areas. The state of research on the teaching of lecturers in South Africa is generally scant (Field, Musset \& Álvarez-Galván, 2014, p. 10). A case study by Watson and Wedekind (2016) uses a best-practice example of an electrical engineering lecturer in order to find a pedagogically and didactically valuable education at a TVET college. Zungu examines potential relationships between the development of trainees' competencies in electrotechnical jobs and the curricular content as well as institutional conditions (2016, p. 61). The vast majority of published empirical studies related to African VET focus on the general circumstances of TVET colleges, either compared to other (African) countries or explicitly for South Africa as an object under investigation (McGrath, 1998; Lumby, 2000; Letseka, 2004; Young, 2006; Wedekind, 2008; Marope, Chakroun \& Holmes, 2015; Arfo, 2015; Akoojee, 2016; Allais, 2011a, 2011b \& 2017).

Several publications from international research networks list a broad spectrum of qualifications for teachers at vocational schools in South Africa (Papier, 2008, p. 7; European Commission, 2014, p. 52; Arfo, 2015, pp. 20-22; Green, 2018). Accordingly, TVET college lecturers possess several different qualifications or are missing qualifications (Ibid.). Only a small minority of vocational school teachers possess both work experience as well as technical knowledge and pedagogic-psychological qualifications (Papier, 2008; Green, 2018). If the qualification guidelines published by the South African government in 2013 (National Qualification Framework, NQF) were to be used as a set of requirements, then one in every five lecturers in South Africa would fail to satisfy those requirements (European Commission, 2014, p. 53). This difficulty is further confirmed by current data and statistics published by the South African Education Administration on the qualification levels of TVET college lecturers $(\mathrm{n}=8,375)$. In this regard, according to Green (2018), $4.8 \%$ of lecturers are academically and vocationally qualified as school teachers $(n=400), 33.1 \%$ are academically qualified as college lecturers $(n=2,774), 36.3 \%$ possess only an academic qualification $(n=3,037), 20.6 \%$ possess no qualification $(\mathrm{n}=1,726)$ and the remaining $5.2 \%$ cannot be accounted for statistically.

If the state of research on policy transfer shows room to improve (Barabasch \& Wolf, 2011), then existing individual general and particular clues can serve as points of connection in order to secure a sustainable transfer of international educational projects. We can thus assume that the probability of transferring model projects, such as the further training of South African lecturers, increases as long as the potential recipients of the model project share the intended goals of the project, are convinced of its effectiveness and assume its practicability under the present working conditions. The necessary support must also be available and the transfer concept allow enough room to adapt to the context in line with lecturers' personal experiences (Prenzel, 2010; Barabasch \& Wolf, 2011). 
In summary, we can determine that one in every five lecturers at a South African vocational college possesses no academic and vocational qualification to teach (i.e. at least three years full-time university tuition with an NQF grade of at least 6 or higher). The multitude of lecturers' differing qualifications, in addition to missing ones, allows the assumption of a generally wide range of available content and pedagogical-psychological and pedagogical content competencies; in developing further training modules, this highlights the importance of further analysing profession-related starting points for vocational school lecturers. Also, based on the knowledge gained from the policy transfer and to ensure and support a sustainable safeguarding of the transfers in the TRAINME programme, we can establish the necessity for a further systematic judgement of (1) the educational policy and general curricular framework, (2) the general situation regarding vocational schools in South Africa and (3) the actual, profession-related need for further lecturer training in the specific fields of electrical and metal engineering.

\section{Approach to the Study}

\subsection{Research Goals and Methods}

Faced with the significantly limited empirical findings available on the training of vocational lecturers in South Africa, it would seem necessary to establish a continued training concept in the electrical and mechanical engineering fields to gain a better, more systematic overview of the subject-specific qualifications, needs and other determining factors of South African vocational teaching education. Over the course of the three case studies in this paper, the following research questions will be investigated:

1. What are the institutional, individual and organisational framework conditions at public TVET Colleges in South Africa?

2. What profession-oriented qualifications do TVET lecturers in South Africa possess?

3. Based on their perspectives, what needs for further education training do South African TVET lecturers have?

This project poses a challenge in more than one way. Firstly, as mentioned, the qualification level(s) of vocational lecturers vary to a great degree. Secondly, it is to be expected that even in the event of a survey of potential lecturers, with minimal effort for the participants, only a partial image of the situation will be revealed. Against this backdrop, a methodical approach involving three case studies was chosen, specifically focussing on the following. 
- Case Study 1 aims to judge the educational policies and curricular framework of lecturer education in South Africa and was conducted as a qualitative content analysis (Lamnek, 2005) of educational policy and curricular documents.

- Case Study 2 aims to judge the further training possibilities in the context of the wholistic, scholastic situation from the perspective of vocational college practices and educational administration experts. The methods used included structured group discussion as a type of focus group (Morgan, 1996; Dürrenberger \& Behringer, 1999; Schulz Mack \& Renn, 2012; Mäder, 2013) and interviews.

- Case Study 3 focusses on a systematic knowledge of the description of further training needs from the perspective of South African lecturers at vocational colleges (TVET colleges). A quantitative survey study was conducted, where $n=309$ teachers from South Africa took part.

\subsection{Conducting the Case Studies}

For Case Study 1, different educational policy documents were made available through the DHET. The extraction of the data for Case Study 2 occurred in Johannesburg during a twoday conference in March 2018, entitled Towards a Continuing Professional Development (CPD) Framework for TVET Colleges, planned and conducted by the South African Department for Higher Education and Training. Both South African directors and lecturers at vocational colleges took part in this conference. All participants of the conference $(n>200)$ were divided amongst six large groups in order to form focus groups. These groups were then divided into five further subgroups of 5-8 participants each. The respective results were then compiled in reverse order to the original division. First, the subgroups exchanged ideas and thoughts after the first work phase. Then a representative of the groups presented the combined results in a plenary session. Both the audiovisual recordings of the presentations of the respective focus groups, totalling approximately one and a half hours (Case Study 2), and the educational policy documents (Case Study 1) were evaluated using a content-analytical method based on Mayring (2007). The quantitative data analysis in Case Study 3 was conducted using pertinent statistical methods (Bortz \& Döring, 2006). 


\section{$4 \quad$ Findings}

As part of the analysis, extensive information about the VET sector in South Africa and its operational framework was gathered within the three conducted studies. Against the backdrop of a wealth of information, selected results are presented which, in a systematically justified way, show the current state of affairs in scholastic practice and in the professionalisation of vocational teachers in South Africa. The display of the findings is based on the three studies and is closely based on the context factors of a policy transfer explained in the first section (Phillips \& Ochs, 2003).

\subsection{Case Study 1: Document Analysis}

In Case Study 1, three central educational policy documents - the White Paper (2013), the Green Paper (2012) and the Government Gazette (2013) - were evaluated in a contentanalytical way in light of the reform efforts and the current targets of vocational college lecturer training in South Africa. The White Paper (DHET, 2013b) and the Government Gazette (DHET, 2013a) are considered especially significant in this context. Considering the first four factors defined by Phillips and Ochs (2003, pp. 329-330) - (1) guiding philosophy of the educational structure, (2) goals and standards of education, (3) rules and strategies of education and (4) enabling structures - the documents are examined chronologically.

Since the Federal Education and Training Act ${ }^{5}$ (FET) of 1998, several reforms have been passed which provide a look into the philosophy, goals and standards of the educational system in South Africa and the desired changes in the work and educational training in TVET colleges (Papier, 2008, p. 6; European Commission, 2014, p. 43). One central reform was the fusion of 152 colleges into 50 central campuses with different fields of specialisation (DHET, 2012, p. 20; European Commission, 2014, p. 43). The reform aimed to neutralise local differences between colleges and states and to establish equity as well as the same available opportunities within population groups (Ibid.). Further reform efforts included the establishment in 2007 of the National Certificate of Vocational Training, under which dual training programmes were replaced with theoretically guided full-time education programmes at colleges. Due to pressure from the private sector and the 'college community', the intention to introduce purely academic/scholastic full-time education programmes was reconsidered, and dual training programmes were readmitted. The reform was provided with significant financial resources in the hopes that the reputation of FET colleges would increase (Wedekind, 2016, p. 136). Colleges were also unable to identify with an academic orientation and

5 Federal Education and Training Act: This law signals a radical, continuous and currently still ongoing change in the vocational sectors in South Africa. In this article, this change is addressed in the context of the technical field(s). 
instead focused on a practical and more vocationally oriented gaining of competencies (Ibid., pp. 43-45). In 2012, FET colleges were renamed TVET colleges.

A preliminary conclusion reached in 2012 by the DHET found that the desired effect (improvement of the reputation of vocational colleges and their diplomas) was far from being reached (The Presidency, 2012; DHET, 2012). TVET college graduates are often seen by the labour market as subpar, which, amongst other factors, comes down to the lack of practical phases during their college education and the lack of cooperation between firms and the vocational colleges (Akoojee, 2016, p. 4). Wedekind's analysis for the South African Qualifications Authority (SAQA) shares this conclusion on the apparent failure of reforms and adds: '... The reforms have not only changed the "what" and "how" of the lectureship, but also the entire existence of institutions, students and the entire vocational education establishment that effects these reforms' (2016, pp. 135-136).

The Government Gazette focuses on the professionalisation of lecturers and describes various areas of competence and their requirements for TVET lecturers. Professional linguistic competence, theoretical and practical expertise and a knowledge of central vocational requirements in the workplace are thus regarded as essential. This knowledge and these skills are to be gathered and collected into several different training programmes. But there is no further elaboration on concrete learning content, how this professionalisation will take place or who will conduct it (DHET, 2013a, pp. 9-32). The HEQC ${ }^{6}$ is responsible for the certification of university courses of study, which orient themselves on the 'Policy on Professional Qualifications for Lecturers in Technical and Vocational Education and Training' (DHET, 2013a, pp. 2-4).

The subtitle of the White Paper, 'Building an expanded, effective and integrated post school system' (DHET, 2013b, p. 1), reflects the central content and goals contained therein. On a societal level, an improvement in social, cultural and economic relations is sought. Social inequalities must be balanced out and apartheid overcome. Further, the improvement of the reputation of public TVET colleges is of paramount importance. Since Lumby (2000, p. 101) realised early on the importance and effects that vocational training at TVET colleges has with respect to both the society and economy of South Africa, it has been determined that societal and historical events during the apartheid era as well as an inequality of resources in South Africa have had a profound effect on the education and development of the country (Allais, 2011a; Field, Musset \& Álvarez-Galván, 2014). Despite the end of apartheid and the attempted reforms intended to bring equal opportunities, the after-effects of apartheid policies are still visible today in society and the educational system (Allais, 2011a; DHET, 2012; Field, Musset \& Álvarez-Galván, 2014). The 'special' societal conditions in South Africa are a recurring theme even in reformation attempts in the fields of vocational training (Allais, 2011a; Wedekind 2016, p. 192). The formation of vocational training is thus affected by histo-

6 Higher Education Quality Committee of the Council on Higher Education. 
rical and societal events and must therefore be viewed in this context (Allais, 2011a). There is also a lack of sustainable cooperation between industry and colleges in vocational education (DHET, 2013b, p. 75).

An OECD review from 2014 suggests to cope with the current challenges by providing topic-specific recommondations. Some of there central points are:

1. Vocational programmes must be made more attractive. Therefore simplifying vocational pathways by merging VET programmes on the upper secondary level into two main tracks as well as offering second chance VET programmes would be necessary. Further it is recommended to actively support the acquisition of diplomas and certificates.

2. Artisan skill sets should meet the demands of the labour market. While current VET programmes not offering the required skills demanded by industry, the gap can be closed by setting workplace exposure from voluntary to mandatory for vocational programmes as well as establishing a committee which is responsible for the cooperation between TVET colleges and industry and the co-ordination.

3. Reduce administrative costs of the current levy grant system and initiate a reform to facilitate the process.

The European Commission's report from 2014 concludes that while various reforms in South Africa have commenced, implementation thus far has not taken place, and lecturers are still being employed who do not possess the necessary qualifications or competencies (European Commission, 2014, p. 55). A potential cause of this is thought to be an acute lack of lecturers, a situation which exists in many colleges. In 2012, a lecturer had an average of 55 students (European Commission, 2014, p. 53). The state of research is poor regarding the actual level of implementation as well as the often criticised 'mentorship programme', which aims to assist in the professionalisation of lecturers. Papier recommends an evaluation of the existing mentorship programme as well as an increased orientation towards the German system for such matters of professionalisation (Papier, 2008, p. 20).

The following quote defines the central challenges for teachers at TVET colleges:

Vocational teachers are ... required to span these two spheres (work and education) and embrace a dual identity that combines liberal education and economic enterprise, placing them in a state of tension between 'industry expert' and 'expert educator' identities, even though they are dislocated from both traditional sites - the industrial workplace and the traditional school. (Papier, 2011, p. 106)

When considering the societal perspectives, this guiding thought forms a bridge between theory and practice for the future professionalisation of TVET lecturers. To gain a further 
understanding of the current situation with respect to the education of teachers, especially in regards to the actual college-practical needs, the findings of the focus group study will be explained in the next section.

\subsection{Case Study 2: Focus Group Study}

An analysis of the focus group data yields the following four central categories: Completed Further Training (61 codes), Motivation and Mindset (83 codes), Need for Further Training (44 codes) and External Circumstances (69 codes), totalling 257 codes across all four categories. Case Study 2 thus focusses especially on the aspect of 'enabling structures' from the perspective of teachers, as introduced by Phillips and Ochs (2003, p. 329).

Category 1 (Completed Further Training): The qualitative results indicate that the participants at the conference, who also took part in the case study, have rarely taken part in further training over the past five years. The case study participants' name various single further training programmes in pedagogical, technical and curricular fields as well as programmes for further personality development. Thematically, the sphere of pedagogy includes further training dealing with cultural diversity in the classroom, equal treatment, inclusion and classroom management or $\mathrm{PGCE}^{7}$. The technical sphere includes the themes of CAD and $\mathrm{CNC}$ mentioned by one group. Aside from one existing curricular further training programme, all focus groups especially highlight further training programmes whose core goal is the development of leadership ability. The material content and competencies which these programmes teach cannot be identified using the available data. Against the backdrop of the low number of participants in further training programmes, the question of why this is the case is posed.

Category 2 (Motivation and Mindset): The results of this category are definitive and overwhelmingly point towards an extrinsic motivation for participation in a further training programme. Such participation is justified with additional financial incentives or improved career advancement opportunities. Only a few associate participation at a further training programme with, for example, the personal goal of delivering better and more wholistic instruction. Statements like the following are rare: "We want to leave the sector because it is not motivating [Salaries], but we are driven by passion to take the skill to the rural areas where we come from" (EP5, 599-601) ; a majority of interviewees indicate financial advancement as the biggest motivation to take further training. On the other hand, transformative factors were also extracted from the transcripts. Some groups determined that they would be intrin-

7 PGCE = Postgraduate Certificate of Education. PGCE includes a 1- or 2-year, on-the-job pedagogical further training initiative:

8 EP5, 599-601: 'EP5' stands for 'Ergebnispräsentation der fünften Gruppe' (Results presentation of the fifth group). The Numbers '599-601' indicate which part of the transcript the citation is extracted from: 
sically motivated if, for example, they were to take part in forming the curriculum or received more recognition for completing qualifying programmes.

Category 3 (Need for Further Training): On the whole, it becomes clear that in the content knowledge, pedagogical content knowledge (didactics) and pedagogical-psychological competencies, there is a central need for further training. In the content knowledge sphere, there are needs in cooperation with the digitalisation of the professional world (in addition to classical CAD and CNC training programmes and themes). This becomes more obvious considering the following:

From our group as well there was a whole issue about preparation for the fourth industrial revolution. We also spoke about the importance of basic research skills. You know that's required for a lecturer to meet the changing environment; reskilling to meet technological changes have been discussed, but also utilising technology in the classroom is an area that we found needed to look at. $(E P 4,375-380)$

Observed across all groups is a need for further training in the methodological usage of digital media during classes and the construction of appropriate and suitable e learning materials in the field of pedagogical content knowledge. In the pedagogic-psychological field, themes of inclusion, dealing with cultural diversity and individual training/advancement and the rating of students with learning difficulties or special needs is mentioned. Further training in class leadership, conflict resolution, project management, digital media and social networks is also classified as urgent.

Category 4 (External Circumstances): A central critique from all groups is the lack of appreciation received for taking further training. It is lamented that despite the successful completion of further training programmes and the attainment of higher qualifications (e.g. a master's degree), there are no chances of career advancement, and there is no increase in payment. This aspect - next to the problem of securing substitute lecturers and the financing of further training programmes - seems central to the general lack of motivation to participate in and complete further training programmes. A majority of the groups also sharply criticise the current mentorship programme for young lecturers. This is justified through the few pedagogic-psychologic, pedagogical content knowledge and content knowledge competencies of the mentors as well as through missing constructive and qualified feedback about the teaching of young lecturers. The interviewees also wish for significantly closer cooperation with the relevant industry, so that students as well as lecturers can gather practical experience in subject-specific companies.

Overall, it would be desirable to be able to make more statements on concrete matters regarding the need for further training. It would also be interesting to understand what qualifications lecturers bring with them from prior education. As the answers obtained from the 
focus groups were generally broad, this epistemological interest could not be satisfied here. Therefore, a questionnaire was authored for this purpose. The results of the survey, given in section 4.3, close the epistemological gap. However, it remains an open question how many persons in one focus group had taken part in the further training programme mentioned. One of the advantages of the survey is in the scope of field research on the philosophy of the educational systems and structures (Phillips \& Ochs, 2003, p. 329). A great degree of transparency in the field of vocational education in South Africa was established through the large number of participants.

\subsection{Case Study 3: Questionnaire Survey}

Participants in the questionnaire case study numbered 309 persons ( $n=309)$, of whom $24.9 \%$ answered the questionnaire in a paper-pencil version as part of the two-day DHET event in Johannesburg while $75.1 \%$ used the online link to the questionnaire. The representative sample consists of $20.7 \%$ female participants $(n=64)$ and $78 \%$ male participants $(n=241)$, and $1.3 \%(\mathrm{n}=4)$ give no indication of gender. Lecturers teach an average of 29.9 hours per week. The average age of the participants is 44 years $(\min =21, \max =64)$. The participants are divided as follows with respect to areas of work: constructional engineering (1.2\%), electrical engineering (37.1\%), mechanical engineering (31.7\%), automotive engineering (9.1\%) and other fields of work (20.9\%).

The questionnaire participants also possess various profession-oriented qualifications; 17.9\% indicated a Bachelor of Education (BEd), and 7.3\% indicated a Master of Education (MEd) as pedagogic qualifications. A Postgraduate Certificate of Education (PGCE) was completed by $18.5 \%$ of participants. A Diploma in Education (DE) was indicated by $8 \%$, a Higher Diploma in Education (HDE) by 6.6\%, a National Higher Diploma (NHD) by 4\%, a National Professional Diploma in Education (NPDE) by 13.9\%, a Teacher Diploma (TD) by $11.9 \%$ and a Technical Education (TE) by $1.3 \%$ as pedagogic qualifications. Meanwhile, $10.6 \%$ indicated miscellaneous qualifications.

Developmental needs from a teacher perspective: The case study participants realise the greatest need of development in the content knowledge area of competencies (e.g. the content/themes: new technologies, control engineering, CNC, electronics and information technology). About one in ten participants identifies a further development need, in the pedagogical content knowledge (didactic) area (e.g. the topics/themes of lesson planning, execution and methods), in pedagogic-psychological knowledge (e.g. the topics/themes of assessment and classroom management) and in organisational knowledge (e.g. the topics/themes of curriculum, infrastructure and resources). 
Training needs according to lecturers

$(n=309)$
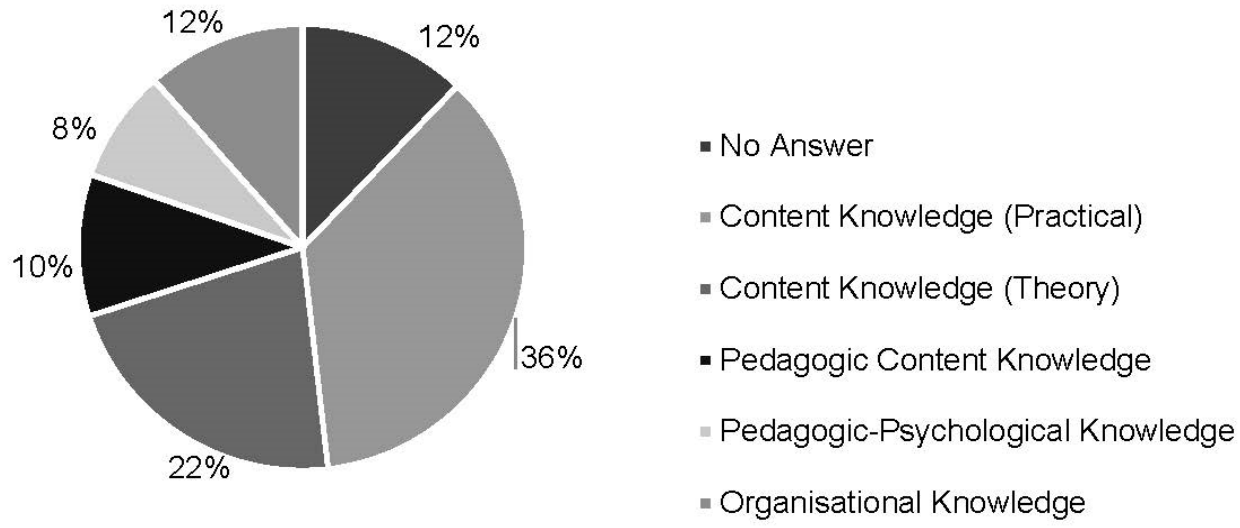

- Organisational Knowledge

Fig. 1: Training needs according to lecturers

It is observed by lecturers that there is a central developmental need for modern technology, and they are interested in practically oriented further training programmes and better cooperation with the industry. The following are two sample answers from the written feedback:

New technology in the field of mechanical, electrical, and electronics, and mechatronics; the implementation of new technologies linked to each subject contents, new labs and workshop ( $M, 43 Y$, $M E$ \& $E E, 253)^{9}$. In the training process more hands on tutoring should be adhered to. Most Nated and NCV Programmes focusses on mostly theoretical concepts whereby more practical training should be implemented. Within the curriculum more focus to be placed on the practical content as industry requires that when students are placed that they are able to perform certain practical tasks. (M, 48Y, EE, 190)

An immediate need for further training is seen by lecturers as follows. In pedagogical-psychological themes, $27 \%$ indicate assessment, moderator, methods, psychology, interests/motivation and individual teaching. In pedagogical content knowledge themes, 7\% indicate lesson planning, class attendance and curriculum. In content knowledge themes (working field: electrical engineering), 22\% indicate information technology, SPS, electronics, electrical machines and control technology. In content knowledge themes (working field: mechanical engineering), $9 \%$ indicate $\mathrm{CNC}, \mathrm{CAD} /$ sketching and manufacturing engineering/machines for the manufacturing of manual tools. Practical training in the form of sitting in on companies and the application of new technologies is desired by $24 \%$, while $11 \%$ declined to answer.

9 (Gender, Age, Class Subject(s) (ME: Machine-Engineering, EE: Electrical Engineering), Questionnaire Number). 
In order to learn more about the various assistance needs during practical teaching challenges, the participants were asked an open question on the perceived challenges and learning requirements of trainees. The results are clustered in the categories of the cognitive, constituting, conative and motivational determinants of the trainees (Fig. 1). The participants particularly identify problems with cognitive determinants ${ }^{10}$ of trainees (69.1\%). Many of the participants also identify learning problems associated with (missing) language competencies, which become clear in the wake of the following answers: "Language barrier and lack of technical exposure/thought what their career choice require prior to learning" ( $\mathrm{M}, 40 \mathrm{Y}$, $\mathrm{EE}, 8$ ) and "Language is a big challenge with a number of students, they simply don't know enough English” (M, 41Y, EE, 150).

Problems in the field of constituting determinants (14.3\%) are viewed by lecturers as financial and societal problems and learning difficulties, for example "concentrating for long when teaching theory" (M, 28Y, ME, 167) or "learning disabilities - e.g. autism" (F, 49Y, Other, 29). The following is stated in regards to conative (volitional) determinants, such as learning strategies, learning aims and lack of time: "Most of them struggle to study on their own" (M, 38Y, ME, 77), "lack of effective study methods, time management" (F, 54Y, Other, 302) and "They do not know how to study" (M, 48Y, EE, 295). In regards to motivational and affective determinants, teachers write the following: "They are very lazy, disobedient and passive" (M, 56Y, ME, 228) and "In some case, lack of motivation and self believe" (M, 37Y, EE, 173).

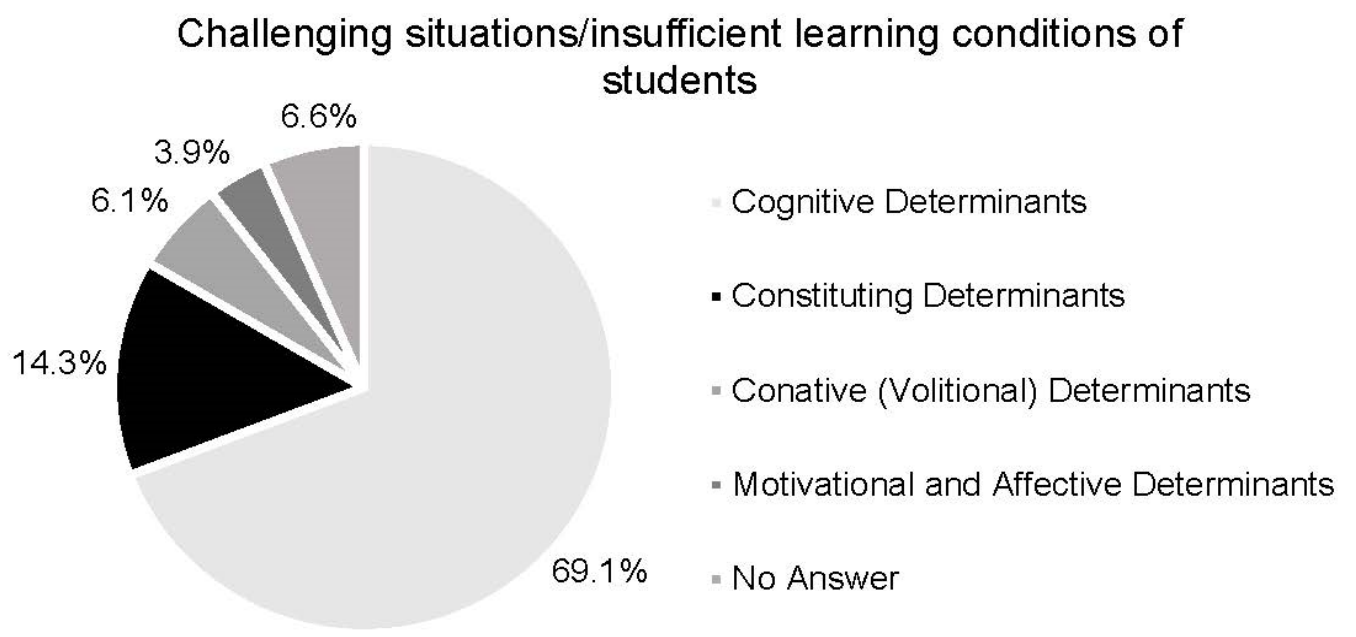

Fig. 2: Challenging situations/ insufficient learning conditions of students

\footnotetext{
10 Amongst others, intelligence, background knowledge and basic competencies are also considered part of cognitive determinants (Helmke \& Schrader, 2001, p. 90). Also amongst others, learning strategies and learning styles are considered part of conative determinants (Helmke \& Schrader, 2001, p. 90; Wang, Haertel, \& Walberg, 1993). Interest and motivation are considered part of motivational and affective determinants, amongst others (Helmke \& Schrader, 2001, p. 91) and amongst others, biological features such as age and gender or learning difficulties are considered part of constituting determinants (Helmke \& Schrader, 2001, p. 91).
} 
When asked about cooperation with companies, $47.3 \%$ stated that a basic cooperation exists. When asked what makes up this basic cooperation, $80 \%$ state that the partnership involves potential job placement, $14 \%$ state that the partnership involves visiting businesses and $6 \%$ state that they are proposing partnerships.

About a third of the lecturers (33.7\%) recognise that they invest more than half their teaching time in practical learning phases. Only $55.7 \%$ of the students take part in this practical teaching, however, as additional fees arise for trainees in acquiring further qualifications (DHET, 2012, pp. 23-28).

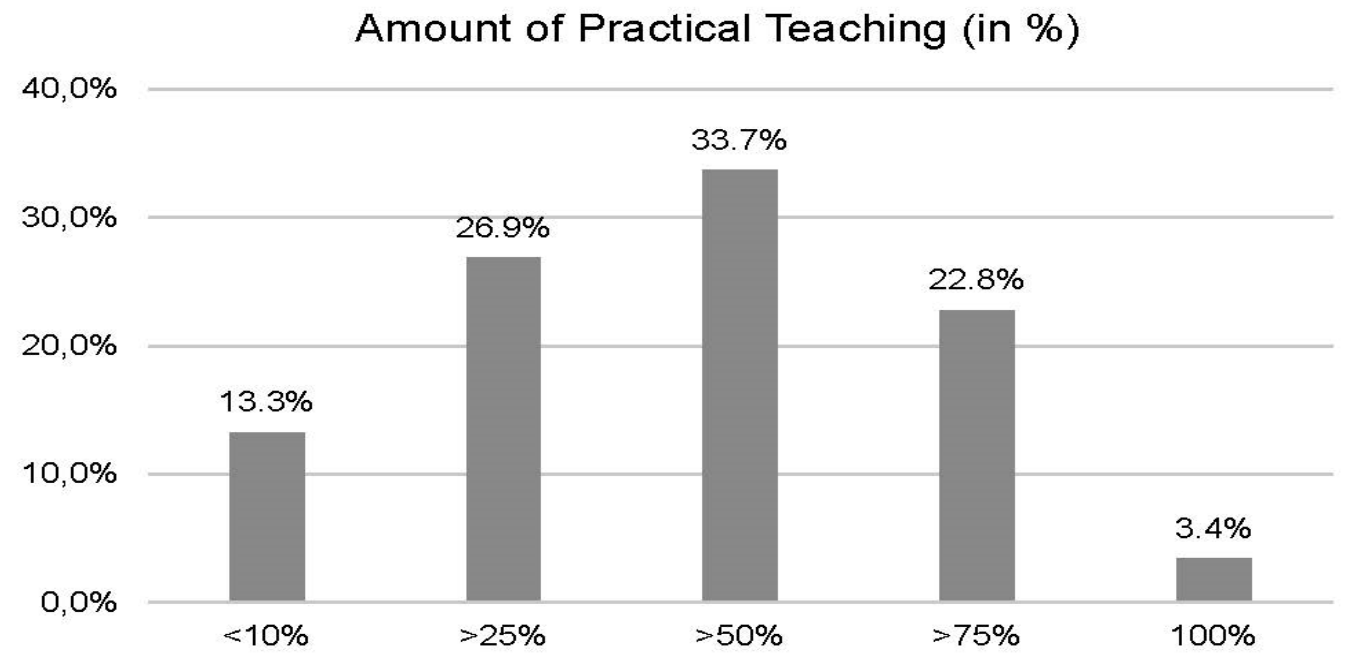

Fig. 3: Amount of Practical Teaching (in \%)

An urgent need for technological equipment is also seen by participants. Lecturers highlight for example the need for computers (31.6\%), the Internet (7.4\%), projectors/overhead projectors (30.1\%) and other learning models (9.6\%). For practical teaching/lessons, a special need is determined for CNC machines/machines to manufacture manual tools (22.7\%), electrical machines/equipment (28\%) and control technology (16.6\%).

\section{Discussion}

Based on the situation as described in the first section, this research aimed to systematically analyse (1) the educational policy and curricular circumstances of vocational teacher education in South Africa, (2) further training conditions in the context of the scholastic/academic background from the perspective of practical vocational school and educational administrative experts as well as (3) the provision of descriptive knowledge of further training needs of South African vocational college lecturers at TVET colleges. The results from the three case 
studies will be discussed in the light of the six previously mentioned context factors of policy transfer, as defined by Philipps and Ochs (2003).

The results of the document analysis (Case Study 1) find that the educational policy desire to improve vocational education and to professionalise teachers through various reforms has manifested and begun, though it has only partially been implemented. The reasons for this are various and can be partially attributed to the "Enabling Structures" which are still significantly affected by the special societal power relations and history of the country, especially apartheid and the unequal distribution of opportunities, for example in education. The "Guiding philosophy" of the educational system as well as the educational establishment is fundamentally affected by this, and this makes the training of professionals more difficult (DHET, 2012, p. 13). The discrepancy between the standard of education received and companies' expectations of college graduates' skills is striking. In order to reach the self-imposed "Ambitions Goals" to improve TVET lecturers' qualifications, new "Strategies" were formulated with the Government Gazette, focussing on a higher standard of professionalisation of lecturers. In reality, however, the results of the document analysis concur that this defined standard has thus far not been reached by at least one in every five lecturers. The results also point towards insufficient cooperation between the industry and the vocational colleges in terms of practical training, and there seems to be a need for an optimisation of the circumstances in the training of lecturers, which can be assigned to the context factor "Strategies". In comparison to Germany, although a company-based dual training system has existed since the 1960s, there is still a tremendous lack of collaboration between vocational schools and companies (Gessler, 2017, p. 164). But notwithstanding this situation, with reference to the passed reform initiatives, it is clear that a need for reform has been recognised along with the will to reform the existing system. With regard to the first four context factors, the results show that the first three factors seem to be currently subject to a change process, while the fourth factor, the "Enabling Structures", has further optimisation potential that has yet to be identified and exploited.

The results of the focus group study (Case Study 2) in regards to further training programmes for lecturers give several clues about the supporting and restricting factors which constitute lecturer training in South Africa. The predominantly low income positions and career advancement opportunities in the professional field of vocational training, a lack of societal appreciation, an insufficient amount of guidance through mentors, the perceived lack of quality of further training courses as well as the limited financial situation at TVET colleges pose significant restricting factors for further training of South African lecturers, and they form fundamental obstacles. These barriers have also been observed and analysed in German research and literature in further teacher training studies (Richter, Richter, \& Marx, 2018). The factors mentioned for Case Study 2 thus deliver central points that the willingness for further training of South African lecturers can connect to and positively sti- 
mulate. The results mentioned in this section identify concrete points as to how to further develop the existing "Enabling Structures".

The results of the questionnaire survey (Case Study 3) establish a broad spectrum of qualifications possessed by the surveyed lecturers as well as their further training interests and the classroom methods they employ. It thus provides an insight into the "Techniques" (e.g. the level of teacher training and teaching methods). The results also point towards a concrete need for further training, stemming from the lecturers' specific fields of operation (e.g. dealing with insufficient linguistic skills and the prior knowledge of students). The profession-oriented qualifications possessed by lecturers vary in type all the way from vocational training to a completed university degree. The largest need for further training is identified by lecturers in the field of content knowledge (37\%), followed by pedagogic-psychological knowledge (27\%) and pedagogical content knowledge (20\%). In these results, not only is the context factor "Processes" found, but also subject-specific training needs to improve the teaching "Techniques" are identified.

In summary and conclusion, the results of this paper deliver an empirically justified extension of knowledge on the further individual training requirements and professional qualifications of vocational college lecturers and the perceived further training needs of teachers. The results also offer several varied points of connection for the development of lecturer education in South Africa. According to Andersson, Hellgren and Köpsén, it is imperative to consider 'two intertwined parts - teaching skills and knowledge in the subject that they teach' (2018, p.141) when conceptualising further education training. The professionalisation of South African lecturers should also consider the current challenges posed to the working world by digitalisation as well as considering the changing competence expectations of employers and the pedagogical content knowledge implications for modern learning and teaching arrangements (Zinn, 2017). Otherwise, the gap between the current skill levels of graduates from a public TVET college and the requirements from the industry will become even bigger. This requires strong, stable cooperation with local companies and a programme to finance internships for socially disadvantaged students. By applying the context factors defined by Philipps and Ochs (2003) to the research findings, multiple points of contact for further research will be exposed, including further research on competencies of TVET lecturers in order to develop and provide lecturers with adequate further educational training possibilities. 


\section{References}

Akoojee, S. (2016). TVET in South Africa and the international agenda. Are they transformative? REAL \& NORRAG Policy BRIEF, 1, 1-10.

Allais, S.M. (2017). Occupational standards in the English-speaking world: A dysfunctional product of export? In: S. Bohlinger, T. Dang \& M. Klatt (Eds.), Education policy: Mapping the landscape and scope (pp.435-459). Frankfurt a.M.: Peter Lang.

Allais, S. M. (2011a). The changing faces of the South African national qualifications framework. Journal of Education and Work, 24:3-4, 343-358, DOI: 10.1080/13639080.2011.584696

Allais, S.M. (2011b). The impact and implementation of national qualifications frameworks: a comparison of 16 countries. Journal of Education and Work, 24:3-4, 233-258, DOI: 10.1080/13639080.2011.584685

Andersson, P., Hellgren, M., \& Köpsén, S. (2018). Factors Influencing the Value of CPD Activities among VET Teachers. International Journal for Research in Vocational Education and Training (IJRVET), 5(2), 140-164.

Arfo, E. B. (2015). A Comparative Analysis of Technical and Vocational Education and Training Policy in Selected African Countries (Dissertation, University of Kwa-Zulu Natal, Durban). Retrieved from https://researchspace.ukzn.ac.za/bitstream/handle/10413/13703/Arfo_Ezekiel_Bangalu_2015.pdf?sequence=1\&isAllowed $=y$

Barabasch, A., \& Wolf, S. (2011). Internationaler Poilcy Transfer in der Berufsbildung - Konzeptionelle Überlegungen und theoretische Grundlagen am Beispiel deutscher Transferaktivitäten [International policy transfer in vocational education - Conceptual considerations and theoretical foundations using the example of German transfer activities]. Zeitschrift für Erziehungswissenschaften, 14, 283-307.

Baumert, J., \& Kunter, M. (2011). Das Kompetenzmodell von COACTIV (The competence model of COACTIV). In M. Neubrand (Ed.), Professionelle Kompetenz von Lehrkräften. Ergebnisse des Forschungsprogramm COACTIV (pp.29-54). Münster/New York/ München/ Berlin: Waxmann.

Baumgarten, C., Kress, H., Lassig, P., Medrikat, I., Rechmann, P., Schlich, T., Shahin, S., Solterbeck, D., \& Verfürth, M. (2017). Jahresbericht GOVET 2017 für den Berichtszeitraum 31.05.2015 31.12.2016 [Annual report GOVET 2017 for the reporting period 31.05.2015-31.12.2016]. GOVET [German Office for International Cooperation in Vocational Education and Training]. Bundesministerium für Berufsbildung (Ed.).

BMBF (Bundesministerium für Bildung und Forschung) [Federal Ministry of Education and Research]. (2017a). Duale Berufsbildung schafft weltweit Chancen - Das internationale Engagement des Bundesministeriums für Bildung und Forschung [Dual VET Creates Opportunities Worldwide - The International Commitment of the Federal Ministry of Education and Research]. Rostock. Publikationsversand der Bundesregierung.

BMBF (Bundesministerium für Bildung und Forschung) [Federal Ministry of Education and Research]. (2017b). Richtlinie zur Förderung der Forschung zur Internationalisierung der Berufsbildung [Directive promoting research on the internationalisation of VET]. Bundesanzeiger vom 25.09.2017.

Bortz, J., \& Döring, N. (2006). Forschungsmethoden und Evaluation für Human- und Sozialwissenschaftler [Research methods and evaluation for human and social scientists]. Heidelberg: Springer. 
Deißinger, T. (2001). Berufliche Bildung zwischen nationaler Tradition und globaler Entwicklung. Beiträge zur vergleichenden Berufsbildungsforschung [Vocational education between national tradition and global development. Contributions to comparative VET research]. Baden-Baden: Nomos-Verlag.

DHET (Department for Higher Education and Training). (2013a). Government Gazette Staatskoerant. No. 36554. Pretoria. Retrieved from: http.//www.gpwonline.co.za/Gazettes/Pages/Government-Gazette.aspx

DHET (Department of Higher Education and Training). (2013b). White Paper For Post-School Education And Training. Building An Expanded, Effective And Integrated Post-School System. Pretoria: Government Printer.

DHET (Department for Higher Education and Training). (2012). Green Paper for Post-School Education and Training. Pretoria. Retrieved from: http.//www.saqa.org.za/docs/papers/2012/greenpaper.pdf

Dürrenberger, G., \& Behringer, J. (1999). Die Fokusgruppe in Theorie und Anwendung [The focus group in theory and application]. Stuttgart: Akademie für Technikfolgenabschätzung in BadenWürttemberg.

Euler, D. (2013). Das duale System in Deutschland: Vorbild für einen Transfer ins Ausland? [The dual system in Germany: A model for a transfer abroad?] Gütersloh: Bertelsmann Stiftung.

European Commission. (2014). TVET college lecturer education annex report. Country study Cameroun, South Africa, Ghana, Tanzania, Egypt. European Union: Luxemburg. Retrieved from: http.//ec.europa.eu/dgs/education_culture/repository/education/library/reports/tvet-lecturereducation_en.pdf

Field, S., Musset, P., \& Álvarez-Galván, J.-L. (2014). A Skills beyond School Review of South Africa. OECD Reviews of Vocational Education and Training. Retrieved from: http://dx.doi. org/10.1787/9789264223776-en

Gessler, M. (2017). The lack of collaboration between companies and schools. International Journal for Research in Vocational Education and Training (IJRVET), 4(2), 164-195. doi: 10.13152/IJRVET.4.2.4

Gonon, P. (2009). The quest for modern vocational education. George Kerschensteiner between Dewey, Weber and Simmel. Studies in vocational and continuing education. Bern: Peter Lang.

Green, W. (2018). TVET lecturer qualifications development. Paper presented at the conference: Towards a Continuing Professional Development (CPD) Framework for TVET Colleges, 19.03.2018 in Johannesburg.

Gross, B. (1981). Der Berufsbildungsbereich in der deutschen Entwicklungshilfe [The vocational training area in German development aid]. Bestandsaufnahme, Erfahrungsauswertung. München [u. a.]: Weltforum Verlag.

Hailemicheal, S.W. (2016). Impact of Curricular Reforms in the Vocational Education of Ethiopia (Dissertation, University of Stuttgart, Germany). Retrieved from https://elib.uni-stuttgart.de/bitstream/11682/8749/1/ICR_Final.pdf

Helmke, A., \& Schrader, F.-W. (2001). Determinanten der Schulleistung [Determinants of school performance]. In D. W. Rost (Ed.). Handwörterbuch Pädagogische Psychologie (pp. 90-102). Weinheim, Basel: Beltz.

Krauss, S., Kunter, M., Brunner, M., et al. (2004). COACTIV: Professionswissen von Lehrkräften, kognitiv aktivierender Mathematikunterricht und die Entwicklung von mathematischer Kompetenz 
[COACTIV: Professional knowledge of teachers, cognitive activating mathematics education and the development of mathematical competence]. In: J. Doll \& M. Prenzel (Eds.), Bildungsqualität von Schule: Lehrerprofessionalisierung, Unterrichtsentwicklung und Schülerforderung als Strategien der Qualitätsverbesserung (pp. 31-53). Münster: Waxmann.

Lamnek, S. (2005). Qualitative Sozialforschung [Qualitative social research]. Weinheim, Basel: Beltz.

Letseka, M. (2004). Understanding skills development in South Africa. The Development Education Journal, 11, 19-20.

Lipowsky, F. (2011). Theoretische Perspektiven und empirische Befunde zur Wirksamkeit von Lehrerfort- und -weiterbildung [Theoretical perspectives and empirical findings on the effectiveness of teacher training and further education]. In E. Terhart, H. Bennewitz, \& M. Rothland (Eds.), Handbuch der Forschung zum Lehrerberuf (pp. 398-417). Münster: Waxmann.

Lipowsky, F., Rzejak, D., \& Dorst, G. (2011). Lehrerfortbildung und Unterrichtsentwicklung. Oder. Wie können Wirkungen des eigenen Handelns erfahrbar gemacht werden? [Teacher training and lesson development. Or. How can the effects of one's own actions be made tangible?]. Pädagogik, $12,38-41$.

Lumby, J. (2000). Technical colleges in South Africa. Planning for the future. Journal of Vocational Education and Training, 52(1), 101-118. doi: 10.1080/13636820000200109.

Mäder, S. (2013). Die Gruppendiskussion als Evaluationsmethode - Entwicklungsgeschichte, Potenziale und Formen [The group discussion as evaluation method - History of development, potentials and forms]. Zeitschrift für Evaluation, 12(1), 23-51.

Marope, P. T. M., Chakroun, B., \& Holmes, K. P. (2015). Unleashing the potential transforming technical and vocational education and training. Paris: UNESCO.

Mayring, P. (2007). Qualitative Inhaltsanalyse. Grundlagen und Techniken. [Qualitative content analysis. Basics and techniques] Weinheim: Beltz.

McGrath, S. (1998). National policies and institutional practices. The credibility gap in South African education and training reform. Journal of Vocational Education \& Training, 50, 503-518.

Morgan, D. L. (1996). Focus groups. Annual Review of Sociology, 22, 129-154.

Ochs, K., \& Phillips, D. (2002). Comparative studies and 'cross-national attraction' in education: A typology for the analysis of English interest in educational policy and provision in Germany. Educational Studies, 28(4), 325-339.

Papier, J. (2011). Vocational teacher identity. Spanning the divide between the academy and the workplace. Southern African Review of Education, 17, 101-119.

Papier, J. (2008). England-Africa Partnerships in Higher Education. Supporting Accelerated and Shared Growth in South Africa. Report on the Training of FET College Lecturers in South Africa, England and other international contexts. Retrieved from: http.//www.feti.ac.za/publications/ R2\%20\%20Final_Report_on_Training_of_College_Lecturers.pdf

Phillips, D., \& Ochs, K. (2003). Researching policy borrowing. Some methodology challenges in comparative devices. Comparative Education, 39(4), 451-461.

Prenzel, M. (2010). Mysterious transfer? How research can contribute to the benefit of educational practice. Zeitschrift für Erziehungswissenschaften, 13(1), 21-37.

Richter, E., Richter, D., \& Marx, A. (2018). Was hindert Lehrkräfte an Fortbildungen teilzunehmen? Eine empirische Untersuchung der Teilnahmebarrieren von Lehrkräften der Sekundarstufe I in Deutschland [What prevents teachers from attending continuing education? An empirical study 
of the participation barriers of secondary school teachers in Germany]. Zeitschrift für Erziehungswissenschaft (ZfE), 21, 1021-1043.

Schulz, M., Mack, B., \& Renn, O. (2012). Fokusgruppen in der empirischen Sozialwissenschaft. Von der Konzeption bis zur Auswertung [Focus groups in empirical social science. From conception to evaluation]. Wiesbaden: Springer.

Shulman, L. S. (1987). Knowledge and teaching. Foundations of the new reform. Harvard Educational Review, 57, 1-21.

Terhart, E., Bennewitz, H., \& Rothland, M. (2014). Handbuch der Forschung zum Lehrerberuf [Handbook of research on the teaching profession]. Münster: Waxmann.

The Presidency. (2012). National Development Plan 2030. Our Future-Make it work. Pretoria. National Planning Commission (NPC).

Wang, M., Haertel, G., \& Walberg, H. (1993). What helps students learn? Educational leadership (Alexandria, VA), 51, 4, 74-79. Retrieved from: http://www.ascd.org/publications/educationalleadership/dec93/vol51/num04/Synthesis-of-Research- -What-Helps-Students-Learnđ.aspx.

Watson, A., \& Wedekind, V. (2016). Pedagogy in a TVET college. Being the visible difference - An analysis of a TVET lecturer at work. SAQA Bulletin, 15(1), 161-190.

Wedekind, V. (2016). TVET college lecturers. Biography, knowledge, pedagogy - A summary of the over-arching findings of the SAQA-UKZN Partnership Research. SAQA Bulletin, 15(1), 191-212.

Wedekind, V. (2008). England-Africa Partnerships in Higher Education. Supporting Accelerated and Shared Growth in South Africa. Report on the Training of FET College Lecturers in South Africa, England and other international contexts. Retrieved from: http.//www.feti.ac.za/docs/FET_Research_Report.pdf

Wolf, S. (2011). Arbeitskultur und der Transfer von Berufsbildungselementen in andere Länder [Working culture and the transfer of VET elements to other countries]. Zeitschrift für Berufs- und Wirtschaftspädagogik, 107(4), 543-567.

Young, M. (2006). FET college teachers. A knowledge-based profession of the future. Perspectives in Education, 24(3), S.153-160.

Zinn, B. (2017). Digitalisierung der Arbeit - Kompetenzerwartungen des Beschäftigungssystems und didaktische Implikationen [Digitization of work - competence expectations of the employment system and didactic implications]. In B. Bonz, H. Schanz, \& J. Seifried (Eds.), Berufsbildung vor neuen Herausforderungen - Wandel von Arbeit und Wirtschaft, Berufsbildung konkret (pp. 163176). Band 13. Baltmannsweiler: Schneider Verlag Hohengeheren.

Zlatkin-Troitschanskaia, O., Beck, K., Sembill, D., Nickolaus, R., \& Mulder, R. (2009). Teaching professionalism. Conditions, genesis, effects and their measurement. Weinheim: Beltz.

Zungu, Z. (2016). Curriculum and Competence. Exploring the relationship between competence development and the curriculum; a comprehensive case of two TVET institutions in South Africa. Retrieved from: http://researchspace.ukzn.ac.za/bitstream/handle/10413/12937/Zungu_Zolile_ Nicholas_2015.pdf?sequence=1\&isAllowed $=y$ 


\section{Biographical notes}

Dr Bernd Zinn is a professor at the Institute of Educational Science (IfE), specifically in the Department of Vocational Education focused on Teaching Technology at the University of Stuttgart, Germany. His research areas of focus are teacher education, research in transfer of concepts related to training on the job, internationalisation of vocational training, further academic training of the vocationally qualified, inclusion and diversity as well as educational training and virtual reality.

Kevin Raisch is an associate at the Institute of Educational Science (IfE), specifically in the Department of Vocational Education focused on Teaching Technology at the University of Stuttgart, Germany, within the TRAINME Project. His research interests are focused on internationalisation of vocational training, further academic training of the vocationally qualified and the use of digital media for teaching.

Jennifer Reimann is an associate at the Institute of Educational Science (IfE), specifically in the Department of Vocational Education focused on Teaching Technology at the University of Stuttgart, Germany, within the TRAINME Project. Her focus areas are internationalisation of vocational training and further academic training of vocationally qualified and the use of digital media for teaching. 